\title{
Evaluation of an Internal Standard for Qualitative DART-MS Analysis of Seized Drugs
}

\author{
Edward Sisco ${ }^{a^{*}}$, Amber Burns ${ }^{\mathrm{b}}$, Elizabeth Schneider ${ }^{\mathrm{b}}$, Ikenna Ikpeama $^{\mathrm{b}}$ \\ aNational Institute of Standards and Technology \\ ${ }^{b}$ Maryland State Police Forensic Sciences Division \\ *edward.sisco@nist.gov, 301-975-2093
}

\section{Highlights}

- Implementation of tetracaine as an internal standard for qualitative DART-MS analysis of seized drugs was completed.

- The internal standard allowed for tunable DART-MS sensitivity when processing data using peak intensity thresholds.

- Use of an internal standard eliminated false identifications in negative spectra cause by identification of noise peaks.

- Competitive ionization was observed with some drugs but did not completely suppress signal.

\begin{abstract}
Rapid and accurate screening tools for seized drug analysis continue to be needed due to the complexities associated with the emerging drug landscape. Direct analysis in real-time mass spectrometry (DART-MS) is one technique that has been used for this purpose and is seeing increased implementation due to its ability to provide high-fidelity information rapidly. As with any analytical technique, ensuring data integrity with DART-MS results is critical. To further enhance data integrity and eliminate some of the challenges associated with qualitative analysis of seized drugs using DART-MS, the incorporation of an internal standard was investigated. After evaluating a number of candidate compounds, tetracaine was chosen because of its desirable characteristics. An appropriate concentration of tetracaine was established that provided similar sensitivity to GC-MS for a panel of drugs. The presence of tetracaine in a drug extract was found to cause a reduction in signal for some common drugs due to competitive ionization but did not cause complete suppression of signal at relevant concentrations. Evaluation of a set of 60 representative case samples with and without internal standard found that the presence of internal standard did not negatively impact the results and that its presence eliminated the false identification of noise peaks in negative samples. The use of an internal standard also provided within-sample mass calibration and analyte concentration checks. It also allowed for automated mass drift compensation, removing a time-consuming process for high resolution DART-MS data processing.
\end{abstract}

Keywords: DART-MS; Seized Drug; Internal Standard; Qualitative Analysis; Competitive Ionization 


\section{Introduction}

Direct analysis in real time mass spectrometry (DART-MS) is one of several screening techniques that is seeing increased prevalence in seized drug analysis due its speed, simple sample preparation, and ability to provide accurate, high-fidelity information. Since the invention of the technique, the ability to analyze controlled substances has been shown[1]. Of the forensic applications where DART-MS has been demonstrated, seized drugs has the prevalent footprint[2]. The large body of research highlights a range of applications from traditional qualitative seized drug analysis[3] to quantitative analysis of psychoactive substances in plant materials[4] to identification of emerging drugs[5] to analysis of drug residues for predictive screening[6].

As with any technique, maintaining data integrity is of utmost importance. For DART-MS analysis, especially when equipped with high-resolution mass spectrometers, multiple-layers of data integrity are employed. These include calibration of the mass spectrometer, use of a positive control to demonstrate mass accuracy or fragmentation consistency, and use of a negative control to demonstrate lack of carryover or contamination. An additional layer of data integrity that has not been adopted in qualitative analysis is the use of an internal standard. Internal standards are commonplace in quantitative analysis $[2,4,5]$ and have been validated for qualitative gas chromatography mass spectrometry (GC-MS) analysis of drugs[7]. The use of an internal standard as an additional layer of data integrity in qualitative analysis has several appeals: inclusion of an internal standard provides in-spectrum mass calibration verification for samples, demonstrates that the instrument is working when negative results are obtained, and provides an estimate of analyte concentration. Also, given that DART-MS data is typically processed by looking for peaks above a pre-defined relative intensity in the mass spectrum, the use of an internal can minimize the false identification of noise peaks - which occurs regularly in spectra where a peak significantly above background does not exist. There are potential pitfalls to inclusion of an internal standard given the lack of chromatography and possibility of competitive ionization. Prior research has shown that the signal of low proton affinity compounds can be degraded or even eliminated in mixtures[8,9].

In this work, the use of an internal standard for qualitative analysis of seized drugs was investigated. Through a series of studies, the utility and potential challenges of including an internal standard in the sample analysis routine was identified. These studies encompassed identifying the internal standard compound, tuning its concentration, and measuring competitive ionization against a suite of commonly seen drugs. To evaluate real-world use of the internal standard, a suite of 60 case extracts from mock or adjudicated samples with and without internal standard were analyzed. Ultimately, it was found that the benefits of incorporating an internal standard into qualitative analysis outweighed the potential challenges and provided an increased level of data integrity.

\section{Materials and Methods}

For this work a JEOL AccuTOF 4G LC-Plus mass spectrometer (JEOL USA, Peabody, MA, USA) coupled with a DART-SVP ion source (IonSense, Saugus, MA, USA) was used. Relevant DART settings included operation in 
positive ionization mode with helium as the source gas at a temperature of $400{ }^{\circ} \mathrm{C}$ with an exit grid voltage of +150 $\mathrm{V}$. Mass spectrometer parameters included operation in positive ionization mode with an orifice 1 voltage of +30 $\mathrm{V}$, a ring lens and orifice 2 voltage of $+5 \mathrm{~V}$, and an ion guide voltage of $+800 \mathrm{~V}$. Mass spectra were collected from $\mathrm{m} / \mathrm{z} 80$ to $\mathrm{m} / \mathrm{z} 800$ at a rate of $2 \mathrm{scans} \mathrm{s}^{-1}$. For some of the casework samples an additional run was required to obtain higher fragmentation spectra to assist in compound differentiation. This method was identical except that it used a $+60 \mathrm{~V}$ orifice 1 voltage. Calibration of the mass spectrometer was completed using polyethylene glycol (PEG-600) on a weekly basis. For each run, a multi-point mass drift compensation corresponding to the protonated molecule of tetracaine $(\mathrm{m} / z$ 265.1916) was completed. Sampling was completed using glass microcapillaries that were either dipped into the solution or, for the sensitivity and competitive ionization studies, had solution pipetted onto them.

Data was collected using one-minute analysis runs set up in the sequence table of msAxel (JEOL USA). A postprocessing method was implemented that automatically applied the multi-point mass drift compensation and automatically centroided the data. In each one-minute analysis, the tetracaine internal standard solution was analyzed once followed by three samplings (for casework analysis) or five samplings (for sensitivity and competitive ionization studies) of the solution. An example of the resulting chronogram is shown in Figure 1. An identical approach was used for the samples analyzed without internal standard except a single-point mass drift compensation was used in the post-processing. For the casework evaluation portion of this study, spectra were extracted and analyzed using Mass Mountaineer (Diablo Analytical, Antioch, CA, USA). A single composite spectrum from the three samplings was extracted and searched against an in-house search list with a $\pm 5 \mathrm{mmu}$ $( \pm 0.005 \mathrm{Da})$ tolerance and a $2.5 \%$ or $5 \%$ relative abundance threshold. For the competitive ionization studies, the integrated peak areas were obtained from extracted ion chronograms of the protonated molecules of the drugs.

Tetracaine was used as the internal standard compound and was purchased from Sigma-Aldrich (St. Louis, MO, USA). Methanolic solutions of alprazolam, cocaine, fentanyl, heroin, methamphetamine, and MPP-PICA were purchased from Cayman Chemical (Ann Arbor, MI, USA) and used as is or diluted, volumetrically, in methanol. Samples for the casework study were either adjudicated samples or training samples. All samples were also analyzed by gas chromatography mass spectrometry (GC-MS) to confirm the identification of controlled substances.

\section{Results \& Discussion}

\section{Identifying an Internal Standard Compound}

Identification of an appropriate internal standard was completed by evaluating potential compounds that met several qualifiers given the current DART-MS workflow used at the laboratory. The workflow uses only positive ionization mode and uses methanolic extracts for sample analysis, therefore the internal standard needed to easily produce a positive ion and be readily soluble in methanol. Since the internal standard was to be used a gauge for the approximate concentration of samples (to assist analysts in identifying an appropriate amount of material to be used for creating samples for GC-MS) the compound could not be a commonly observed diluent. Another purpose of the 
internal standard is to act as a mass calibration check and therefore a compound that had a protonated molecule within the typical $\mathrm{m} / \mathrm{z}$ range of most drugs (approximately $\mathrm{m} / \mathrm{z}, 150$ to $\mathrm{m} / \mathrm{z} 450$ ) was needed. The compound could not have a molecular formula that was identical to any compound of interest or, given the mass accuracy of the mass spectrometer in $\pm 5 \mathrm{mDa}$, could not be within $\pm 10 \mathrm{mDa}$ of any compound of interest. The compound could not heavily fragment when using low orifice voltages and form predominantly a protonated molecule. It needed to be stable in methanol over a prolonged time (at least one month), not be prone to carryover, and be cost-effective.

Initial efforts looked at a number of mass check, or mass drift compensation, compounds used in literature to see if they could be potential candidates for an internal standard. Reserpine $\left(\mathrm{C}_{33} \mathrm{H}_{40} \mathrm{~N}_{2} \mathrm{O}_{9}\right)$ has been reported in a number of papers as a mass check compound[10,11], but its high molecular mass (608 Da) made it undesirable for this application. Sugar alcohols, such as xylitol, mannitol, and sorbitol, have also been analyzed[12] and were appealing because of their capability to produce strong positive and negative ions. However, they are poorly soluble in methanol and would require a water-methanol mixture to reach the desired concentrations. These compounds are also common diluents in casework, which could affect data processing approaches. Other compounds such as caffeine, acetaminophen, and quinine also fell into this category. Many quantitative methods leverage the use of deuterated or carbon-labeled internal standards[4,13,14], but these types of materials would be cost prohibitive for high-throughput qualitative drug screening by DART-MS. Tetracosane is a commonly used internal standard for GC-MS analysis[7], but is not easily ionized by DART-MS.
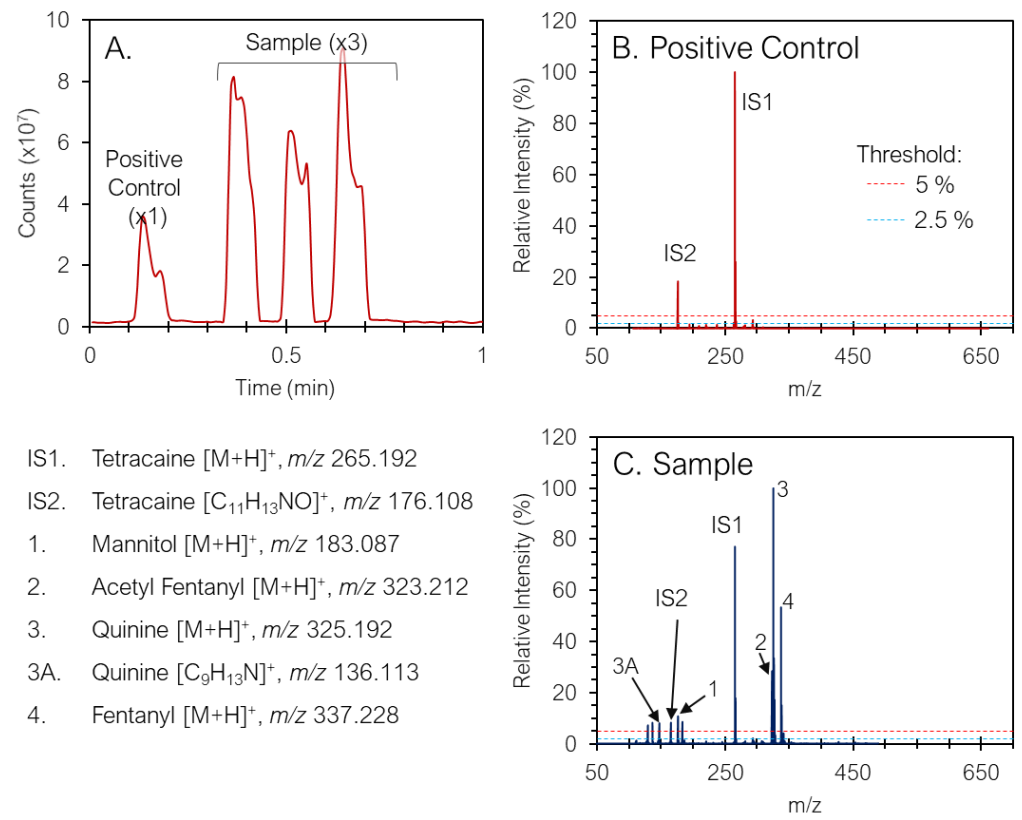

Figure 1. Representative chronogram (A.) and mass spectra (B. and C.) for data collection using the sequencebased approached for Case 18 (Table 2). Example chronogram (A.) shows the single analysis of the tetracaine solution (used as a positive control) as well as the triplicate analysis of the sample. Extracted mass spectra of the tetracaine solution (B.) and sample (C.) are also shown with peak labeling associated with the assignments in the bottom left quadrant. The dotted lines in (B.) and (C.) represent the $5 \%$ (red) and $2.5 \%$ (blue) relative intensity thresholds. 
After investigation and analysis, it was found that tetracaine was a compound that met the needs describe above. The compound had an acceptable molecular weight $\left(\mathrm{C}_{15} \mathrm{H}_{24} \mathrm{~N}_{2} \mathrm{O}_{2}, \mathrm{MW}=264.1878\right)$ and produced, predominantly, an intact molecular ion (as shown in Figure 1). Searching the NIST DART-MS Forensics Database[15,16] and the SWGDRUG Monographs[17] revealed two potential compounds of interest at the same nominal mass as tetracaine - etaqulaone $\left(\mathrm{C}_{17} \mathrm{H}_{16} \mathrm{~N}_{2} \mathrm{O}\right)$ and $\mathrm{Udes} 03\left(\mathrm{C}_{15} \mathrm{H}_{21} \mathrm{FN}_{2} \mathrm{O}\right)$ which is also known as 4-fluoro U-47931E. The accurate $\mathrm{m} / \mathrm{z}$ values for the protonated molecules of both compounds $(\mathrm{m} / \mathrm{z} 265.1335$ and $\mathrm{m} / \mathrm{z} 265.1711$ respectively) were sufficiently different from that of tetracaine $(\mathrm{m} / \mathrm{z} 265.1910)$ that misidentification was not a concern. Analysis of tetracaine did produce a small fragment ion at $\mathrm{m} / z \mathbf{z} 176.1075$ (corresponding to $\left[\mathrm{C}_{11} \mathrm{H}_{13} \mathrm{NO}\right]^{+}$) in addition to the protonated molecule, but it was not found to cause unwanted false identifications of compounds of interest. Using tetracaine was found to be cost-effective and it easily dissolved in methanol. Stability and carryover, which are discussed below, were also found to be acceptable.

\section{Establishing an Appropriate Internal Standard Concentration}

Once chosen, an appropriate concentration of tetracaine was established. For qualitative analysis of seized drugs, GC-MS is the most commonly used instrument for confirmation and, therefore, it is critical that screening tools such as DART-MS be at least as sensitive. Traditionally DART-MS data is analyzed by looking for agreement between peaks in a spectrum above a pre-selected threshold (commonly between $1 \%$ and $10 \%$ relative intensity to the base peak) and a list of $m / z$ values corresponding to known compounds. Using an internal standard, therefore, guarantees a peak with a roughly known intensity will be present in every spectrum and therefore can be used to "tune" the sensitivity of the result by changing its concentration. Given this, an appropriate internal standard concentration was defined as one that provides detection of compounds of interest above the threshold level that is used by the laboratory at a level equal to or lower than the reporting level of the GC-MS systems used for confirmation.

Prior to establishing the internal standard concentration, the limit of detection and reporting limit for three drugs (cocaine, fentanyl, and methamphetamine) was established on eight of the GC-MS systems used for casework at the Maryland State Police Forensic Sciences Division (MSP-FSD). Details on how these values were obtained are provided in Supplemental Information. At MSP-FSD a reportable peak is defined as a peak present in a chromatogram with an abundance of at least 200,000 counts. Across the eight instruments, the average concentration required to produce a reportable peak for cocaine, fentanyl, and methamphetamine (Table 1) ranged from $66 \mu \mathrm{g} / \mathrm{mL}$ to $128 \mu \mathrm{g} / \mathrm{mL}$. Given differences in instrument age and sensitivity, the reporting limit varied across GC-MS systems, with a minimum concentration of $10 \mu \mathrm{g} / \mathrm{mL}$ which roughly corresponded to the average limit of detection for the drugs examined. 
Table 1. Limits of detection and estimated reporting limits for eight of the GC-MS systems used for casework.

\begin{tabular}{|c|c|c|c|c|}
\hline Drug & $\begin{array}{c}\text { Limit of } \\
\text { Detection Range } \\
(\boldsymbol{\mu g} / \mathbf{m L})\end{array}$ & $\begin{array}{c}\text { Average Limit of } \\
\text { Detection }(\boldsymbol{\mu g} / \mathbf{m L})\end{array}$ & $\begin{array}{c}\text { Reporting Limit } \\
\text { Range ( } \boldsymbol{\mu g} / \mathbf{m L})\end{array}$ & $\begin{array}{c}\text { Average Reporting } \\
\text { Limit }(\boldsymbol{\mu g} / \mathbf{m L})\end{array}$ \\
\hline Cocaine & 0.5 to 30.1 & 10.4 & 10.4 to 109.8 & 66.0 \\
\hline Fentanyl & 0.7 to 40.6 & 14.9 & 14.3 to 197.0 & 123.0 \\
\hline Methamphetamine & 4.9 to 48.2 & 9.0 & 17.0 to 198.4 & 128.0 \\
\hline
\end{tabular}

Given a minimum drug concentration of $10 \mu \mathrm{g} / \mathrm{mL}$ was needed to obtain a reportable peak, a series of experiments were completed to establish the concentration of tetracaine necessary to allow for drugs of interest at $10 \mu \mathrm{g} / \mathrm{mL}$ to be reliably detected by DART-MS and to produce peaks above a given relative intensity threshold. Initial studies showed that a tetracaine concentration of approximately $100 \mu \mathrm{g} / \mathrm{mL}(0.1 \mathrm{mg} / \mathrm{mL})$ was required to achieve the desired detection when using a $2.5 \%$ relative abundance threshold. This was verified by analyzing a panel of six drugs (alprazolam, cocaine, fentanyl, heroin, methamphetamine, and MPP-PICA) individually at three concentrations $(1 \mathrm{mg} / \mathrm{mL}, 100 \mu \mathrm{g} / \mathrm{mL}$, and $10 \mu \mathrm{g} / \mathrm{mL})$ each containing tetracaine at $100 \mu \mathrm{g} / \mathrm{mL}$. The relative intensity of the protonated molecule peak for each drug was obtained and the cumulative results are shown in Figure 2. Using a tetracaine concentration of $100 \mu \mathrm{g} / \mathrm{mL}$, detection of all six drugs at $10 \mu \mathrm{g} / \mathrm{mL}$ was achieved. At this concentration, peaks corresponding to cocaine (Figure 2, blue) and fentanyl (Figure 2, yellow) were present above $5 \%$ relative intensity while the remaining four drugs produced peaks with relative intensities between $2.5 \%$ and 5 $\%$. Given these results, a tetracaine concentration of $100 \mu \mathrm{g} / \mathrm{mL}$ was chosen.

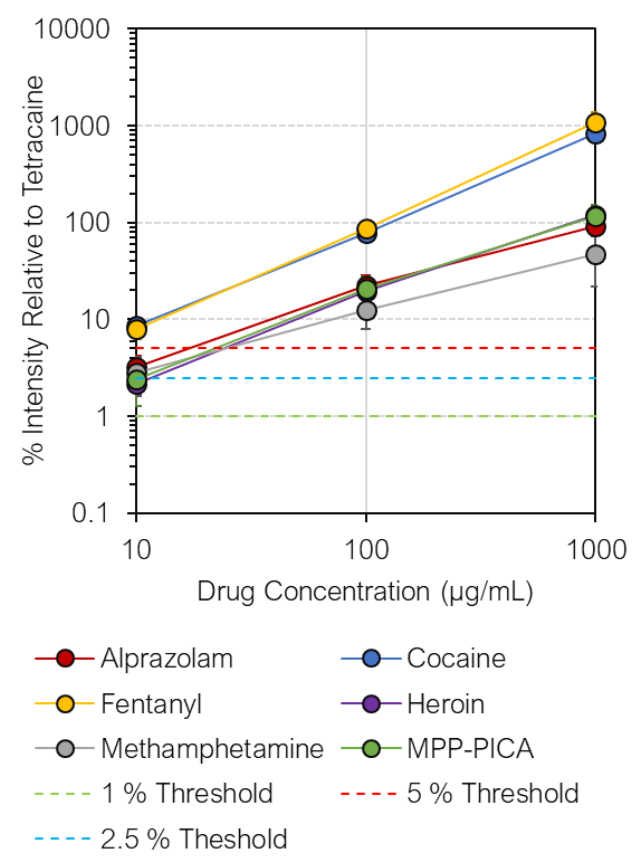

Figure 2. Peak intensity, relative to tetracaine, for six drugs. Three commonly used thresholds ( $1 \%, 2.5 \%$, and 5 $\%)$ are also provided. Uncertainties represent the standard deviation of five replicates. Points above $100 \%$ show that the drug peak was more intense than the tetracaine peak. 


\section{Understanding Competitive Ionization Effects}

With chromatography-free mass spectrometry techniques such as DART-MS, competitive ionization is a concern. Because of the high frequency in which multi-component mixtures are observed in seized drug analysis, the effect of including tetracaine was examined by measuring the degree of competitive ionization across a range of concentrations for the six drugs previously examined. Individual drugs were analyzed at three concentrations (10 $\mu \mathrm{g} / \mathrm{mL}, 100 \mu \mathrm{g} / \mathrm{mL}$, and $1000 \mu \mathrm{g} / \mathrm{mL}$ ) in solutions of both pure methanol and methanol containing tetracaine (100 $\mu \mathrm{g} / \mathrm{mL}$ ). Integrated peak areas of the protonated molecules for each drug were then obtained and the ratios of peak areas for runs containing the internal standard to those without were plotted. The results of this experiment are shown in Figure 3 where points below a ratio of 1 indicate that the presence of internal standard caused reduction in the drug signal due to competitive ionization while a ratio above 1 indicated the presence of internal standard had no effect or an advantageous effect on the ionization of the drug. An alternative representation of this data can be found in Supplemental Figure 1.

At low concentrations, competitive ionization was readily observed for four (alprazolam, heroin, methamphetamine, and MPP-PICA) of the six drugs. Signal suppression was greatest for methamphetamine which demonstrated a $\sim 90$ $\%$ reduction in peak area at $10 \mu \mathrm{g} / \mathrm{mL}$ when tetracaine was present. A similar level of suppression was observed at a concentration of $100 \mu \mathrm{g} / \mathrm{mL}$. For alprazolam, heroin, and MPP-PICA signal reduction of $50 \%$ to $70 \%$ was observed at $10 \mu \mathrm{g} / \mathrm{mL}$ and a reduction between $40 \%$ and $60 \%$ was observed at $100 \mu \mathrm{g} / \mathrm{mL}$. It is important to note that while competitive ionization did occur, detection of all compounds was possible at all levels and the respective peaks were consistently present at or above the $2.5 \%$ relative intensity threshold.

For cocaine and fentanyl, competitive ionization was not observed at any concentration studied, likely due to the high proton affinity of these two compounds. For all drugs except methamphetamine, competitive ionization was not observed when the drug was in excess relative to tetracaine (1000 $\mu \mathrm{g} / \mathrm{mL}$ datapoints). Methamphetamine exhibited a minor reduction in signal at this concentration. 


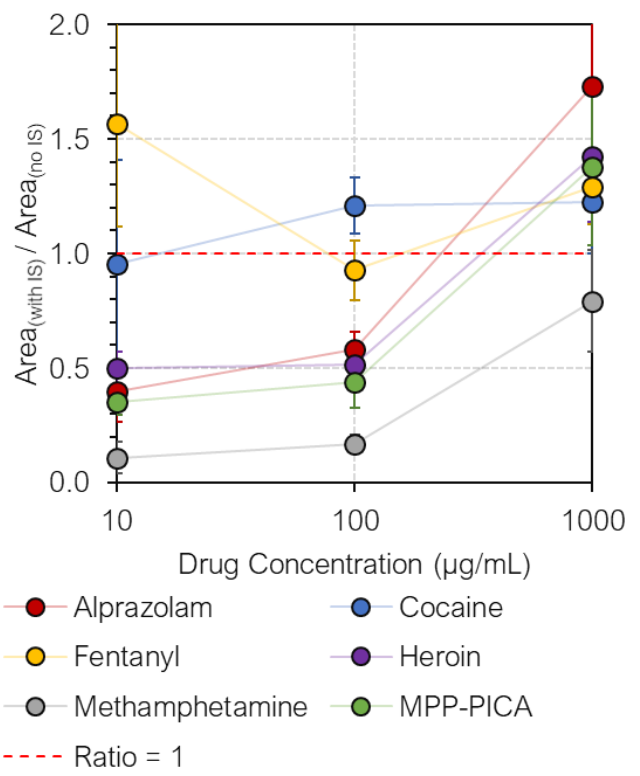

Figure 3. Ratio of the integrated peak area from the protonated molecule of the drug with and without the presence of the internal standard, as a function of concentration. A ratio of 1 (red dotted line) indicates no competitive ionization. Points below a ratio of 1 indicate competitive ionization occurred in the presence of tetracaine while points above a ratio of 1 indicate an increase in drug signal due to the presence of tetracaine. Uncertainties represent the standard deviation of five replicates.

\section{Internal Standard Stability}

Stability of the internal standard over time was evaluated over a two-month period by (1) investigating if the peak intensity of tetracaine dropped over time and (2) monitoring the full scan mass spectrum for the presence of degradation products. The intensity of the tetracaine protonated molecule remained consistent (some variation of signal was observed due to the sample introduction procedure). The presence of the fragment ion at nominal $\mathrm{m} / \mathrm{z}$ 176 was observed in the freshly made solution and was not believed to be a degradation product. Over the twomonth period the peak did not increase in intensity. A separate tetracaine solution that was aged over 3 months did show the presence of a suspected degradation peak at $m / z 208.1332\left(\left[\mathrm{C}_{12} \mathrm{H}_{18} \mathrm{NO}_{2}\right]^{+}\right)$. Given these results, it was determined that the tetracaine solution is stable for short-term use but should be replaced on a monthly or bi-monthly basis.

\section{Analysis of Case Samples}

The final component of the evaluation involved the analysis of extracts from 60 case samples. Extracts were prepared by dissolving a $1 \mathrm{mg}$ to $2 \mathrm{mg}$ aliquot of powder into methanol with the tetracaine internal standard (100 $\mu \mathrm{g} / \mathrm{mL}$ ) and a separate aliquot into methanol without internal standard. Both extracts were analyzed using identical instrument parameters which were outlined above. The spectra of the tetracaine solution without sample (used as a positive control) and the composite sample spectra were extracted and searched using MassMountaineer. Both a $2.5 \%$ and $5 \%$ threshold were used to identify if there was a benefit to using one threshold over the other. 
The summary results are shown in Table 2 along with the controlled substances that were identified by GC-MS. All tetracaine solution without sample spectra (positive control spectra) (120 in total) produced results only for the tetracaine molecular ion $(\mathrm{m} / \mathrm{z}, 265.1916)$ and its minor fragment ion $(\mathrm{m} / \mathrm{z}, 176.1074)$. The sample spectra from extracts with and without internal standard were largely identical. Slight differences between the GC-MS results and one or both the DART-MS results were observed for eight of the sixty samples. Of the extracts containing internal standard, there was one case (Case 42) where identification of all drugs in the mixture was not achieved. Noscapine, which is poorly ionized by DART, and cocaine, which was present at an insufficient amount for reporting by GC-MS, were not identified by DART. The remaining four controlled substances in that mixture were readily identified. For the casework extracts, the relative intensities of the peaks corresponding to controlled substances were above $5 \%$ relative intensity to the base peak for all but three compounds that were present at a low concentration in the sample. These were two instances of heroin (Cases 3 and Case 14) and one instance of ketamine (Case 60). All three of these peaks were, however, present above $2.5 \%$ relative intensity. Importantly, there were no false-positive identifications of controlled substances in any of the samples, including the eight cases that were negative.

For the extracts created in methanol without internal standard, there were no instances where identification of a controlled substance was missed. In four instances (Case 33, Case 40, and Case 42 - two substances) controlled substances in the sample were identified but were between $2.5 \%$ and $5 \%$ relative intensity to the base peak. Unlike the extracts containing internal standard there were ten instances where a hit for a controlled substance was obtained but was not identified by GC-MS (false-positive) (Case 1 - three instances, Case 7, Case 16 - two instances, Case 29, Case 36, Case 40, and Case 41). For two of these (Cases 36 and 40), identification of a false positive occurred in the presence of actual controlled substances, and in one of these instances the peak was below $5 \%$ relative intensity to the base peak. The remaining four cases contained no controlled substances and the hit occurred because noise peaks were present above the $2.5 \%$ or $5 \%$ threshold that fell within the $m / z$ tolerance on an entry in the compound search list used in MassMountaineer. While it is simple to explain the presence of these false-positive peaks, and conformational analysis will further demonstrate that they are not attributable to actual analytes, the use of an internal standard provides a peak with sufficient intensity that noise peaks are not above the threshold in the searching process.

Overconcentration is another concern when analyzing samples by DART-MS, especially high-resolution mass spectrometers, as it can lead to drifts in $\mathrm{m} / \mathrm{z}$ values that can push peaks outside of the tolerance window. The presence of the internal standard in the mass spectra provides an indication of whether the sample is overly concentrated. In this work it was observed that when the internal standard peak was not the base peak in the spectrum and fell below $5 \%$ relative abundance, the dominant peak(s) in the spectra were outside the $\mathrm{m} / z$ tolerance window. While the dominant peak(s) were outside of the tolerance window, the tetracaine peak was within the window, indicating there 
was not a mass calibration issue. Dilution of the sample in methanol containing tetracaine brought the $m / z$ value(s) of the dominant peak(s) into tolerance.

Table 2. Results of analysis of 60 case samples by DART-MS using extracts that contained the tetracaine internal standard (left column) and did not contain the tetracaine internal standard (center column) using a $2.5 \%$ and $5 \%$ threshold for searching. The controlled substances identified using GC-MS are provided in the right column. Excipient results are listed for the DART-MS analyses, but were not used in comparing to the GC-MS results.

\begin{tabular}{|c|c|c|c|}
\hline \# & $\begin{array}{l}\text { Results for DART-MS Analysis with } \\
\text { Tetracaine Internal Standard }\end{array}$ & $\begin{array}{l}\text { Results for DART-MS Analysis } \\
\text { without Tetracaine Internal Standard }\end{array}$ & GC-MS Results \\
\hline 1 & No Compounds Detected & $\begin{array}{c}\text { Androsterone }^{\dagger}, \text { Methoxy-PCP }^{\dagger}, \mathrm{MMB}^{-} \\
\text {FUBINACA } \\
\text { Excipients: Levamisole }\end{array}$ & No Controlled Substances \\
\hline 2 & Methamphetamine & Methamphetamine & Methamphetamine \\
\hline 3 & $\begin{array}{c}\text { Heroin* } \\
\text { MDMA } \\
\text { Excipients: } \begin{array}{c}\text { Caffeine, Mannitol*, } \\
\text { Quinine }\end{array}\end{array}$ & $\begin{array}{c}\text { Heroin } \\
\text { MDMA } \\
\text { Excipients: Caffeine, Mannitol, } \\
\text { Quinine }\end{array}$ & $\begin{array}{l}\text { Heroin } \\
\text { MDMA }\end{array}$ \\
\hline 4 & $\begin{array}{c}\text { Fentanyl } \\
\text { Tramadol } \\
\text { Excipients: Levamisole, Mannitol, } \\
\text { Phenylpropanamide, Pindolol, Procaine }\end{array}$ & $\begin{array}{c}\text { Fentanyl } \\
\text { Tramadol } \\
\text { Excipients: Levamisole, Mannitol, } \\
\text { Pindolol, Procaine }\end{array}$ & $\begin{array}{c}\text { Fentanyl } \\
\text { Tramadol }^{\text {INS }}\end{array}$ \\
\hline 5 & $\begin{array}{c}\text { 4-methyl- } \alpha \text {-PHP } \\
\text { Excipients: Dextrorphan }\end{array}$ & 4-methyl- $\alpha$-PHP & 4-methyl- $\alpha$-PHP \\
\hline 6 & MDMA & MDMA & MDMA \\
\hline 7 & $\begin{array}{l}\text { No Controlled Substances } \\
\text { Excipients: Mannitol }\end{array}$ & $\begin{array}{c}\mathrm{GBL}^{\dagger} \\
\text { Excipients: Mannitol }\end{array}$ & No Controlled Substances \\
\hline 8 & $\begin{array}{c}\text { Heroin } \\
\text { 6-Monoacetylmorphine }{ }^{\Delta}\end{array}$ & Heroin & Heroin \\
\hline 9 & methyl Norfentanyl & methyl Norfentanyl & methyl Norfentanyl \\
\hline 10 & 4-Ethylmethcathinone & 4-Ethylmethcathinone & 4-Ethylmethcathinone \\
\hline 11 & $\begin{array}{c}\text { Dibutylone } \\
\text { Excipients: Caffeine }\end{array}$ & $\begin{array}{c}\text { Dibutylone } \\
\text { Excipients: Caffeine }\end{array}$ & Dibutylone \\
\hline 12 & $\begin{array}{c}\text { Fentanyl } \\
\text { 4-Methyl- } \alpha \text {-ethylaminopentionphenone }\end{array}$ & $\begin{array}{c}\text { Fentanyl } \\
\text { 4-Methyl- } \alpha \text {-ethylaminopentionphenone }\end{array}$ & $\begin{array}{c}\text { Fentanyl } \\
\text { 4-Methyl- } \alpha \text {-ethylaminopentiophenone }\end{array}$ \\
\hline 13 & MMB-FUBINACA & MMB-FUBINACA & MMB-FUBINACA \\
\hline 14 & $\begin{array}{c}\text { Cyclopropyl Fentanyl } \\
\text { Heroin* } \\
\text { Phenyl Fentanyl } \\
\text { Excipients: Caffeine, Mannitol }\end{array}$ & $\begin{array}{c}\text { Cyclopropyl Fentanyl } \\
\text { Heroin } \\
\text { Phenyl Fentanyl } \\
\text { Excipients: Caffeine, Mannitol }\end{array}$ & $\begin{array}{l}\text { Cyclopropyl Fentanyl } \\
\text { Heroin } \\
\text { Phenyl Fentanyl }\end{array}$ \\
\hline 15 & $\begin{array}{l}\text { AB-FUBINACA 2-fluorobenzyl isomer } \\
\text { Excipients: Inositol* }\end{array}$ & AB-FUBINACA 2-fluorobenzyl isomer & AB-FUBINACA 2-fluorobenzyl isomer \\
\hline 16 & No Controlled Substances & $\begin{array}{c}\mathrm{GBL}^{\dagger} \\
\text { Cathinone at } m / z 192^{\dagger}\end{array}$ & No Controlled Substances \\
\hline 17 & Dibutylone & Dibutylone & Dibutylone \\
\hline 18 & $\begin{array}{c}\text { Acetyl fentanyl } \\
\text { Fentanyl } \\
\text { Excipients: Quinine, Mannitol }\end{array}$ & $\begin{array}{c}\text { Acetyl Fentanyl } \\
\text { Fentanyl } \\
\text { Excipients: Quinine, Mannitol }\end{array}$ & $\begin{array}{l}\text { Acetyl fentanyl } \\
\text { Fentanyl }\end{array}$ \\
\hline 19 & $\begin{array}{c}\text { Heroin } \\
\text { Acetyl fentanyl } \\
\text { Fentanyl } \\
\text { FIBF } \\
\text { 6-Monoacetylmorphine*, } \\
\text { Excipients: Caffeine, Mannitol }\end{array}$ & $\begin{array}{c}\text { Heroin } \\
\text { Acetyl Fentanyl } \\
\text { Fentanyl } \\
\text { FIBF } \\
\text { Excipients: Caffeine, Mannitol, } \\
\text { Lidocaine* }\end{array}$ & $\begin{array}{c}\text { Heroin } \\
\text { Acetyl fentanyl (indication) } \\
\text { Fentanyl (indication) }\end{array}$ \\
\hline 20 & $\begin{array}{c}\text { No Controlled Substances } \\
\text { Excipients: Guaifenesin, Quinine }\end{array}$ & $\begin{array}{l}\text { No Controlled Substances } \\
\text { Excipients: Guaifenesin, Quinine, 4- } \\
\text { Fluorophenibut }\end{array}$ & No Controlled Substances \\
\hline 21 & $\begin{array}{c}\text { No Controlled Substances } \\
\text { Excipients: Acetaminophen, Xylitol }\end{array}$ & $\begin{array}{c}\text { No Controlled Substances } \\
\text { Excipients: Acetaminophen, Xylitol }\end{array}$ & No Controlled Substances \\
\hline 22 & Fentanyl & Fentanyl & Fentanyl \\
\hline
\end{tabular}

Page 10 of 15 


\begin{tabular}{|c|c|c|c|}
\hline & XLR11 & XLR11 & XLR11 \\
\hline 23 & JWH-250 & JWH-250 & JWH-250 \\
\hline 24 & JWH-018 & JWH-018 & JWH-018 \\
\hline 25 & $\alpha$-PVP & $\alpha-\mathrm{PVP}$ & $\alpha$-PVP \\
\hline 26 & Eutylone & $\begin{array}{c}\text { Eutylone } \\
\text { Excipients: Caffeine }\end{array}$ & Eutylone \\
\hline 27 & $\begin{array}{l}\text { No Controlled Substances } \\
\text { Excipients: Caffeine }\end{array}$ & $\begin{array}{l}\text { No Controlled Substances } \\
\text { Excipients: Caffeine }\end{array}$ & No Controlled Substances \\
\hline 28 & Methylethcathinone & Methylethcathinone & Methylethcathinone \\
\hline 29 & $\begin{array}{c}\alpha-\mathrm{PBP} \\
\text { 5-Fluoro-AKB48 } \\
\text { Excipients: Mannitol }\end{array}$ & $\begin{array}{c}\alpha-\mathrm{PBP} \\
\text { 5-Fluoro-AKB48 } \\
\text { Stanozolol } *, \uparrow \\
\text { Excipients: Mannitol }\end{array}$ & $\begin{array}{c}\alpha-\mathrm{PBP} \\
\text { 5-Fluoro-AKB48 }\end{array}$ \\
\hline 30 & $\begin{array}{l}\text { Dibutylone } \\
\text { Fentanyl } \\
\text { JWH-250 }\end{array}$ & $\begin{array}{l}\text { Dibutylone } \\
\text { Fentanyl } \\
\text { JWH-250 }\end{array}$ & $\begin{array}{l}\text { Dibutylone } \\
\text { Fentanyl } \\
\text { JWH-250 }\end{array}$ \\
\hline 31 & $\begin{array}{c}\text { Tramadol } \\
\text { Excipients: Sibutramine* }\end{array}$ & $\begin{array}{c}\text { Tramadol } \\
\text { Excipients: Mannitol* }\end{array}$ & Tramadol \\
\hline 32 & JWH-250 & JWH-250 & JWH-250 \\
\hline 33 & $\begin{array}{c}\text { Acetyl fentanyl } \\
\text { Fentanyl } \\
\text { FIBF } \\
\text { Heroin } \\
\text { 6-Monoacetylmorphine }{ }^{\Delta} \\
\text { Excipients: Caffeine, Quinine* }\end{array}$ & $\begin{array}{c}\text { Acetyl Fentanyl } \\
\text { Fentanyl } \\
\text { FIBF } \\
\text { Heroin* } \\
\text { Excipients: Caffeine, } \\
\text { Diphenhydramine*, Lidocaine, } \\
\text { Procaine* }\end{array}$ & $\begin{array}{l}\text { Acetyl Fentanyl }{ }^{\mathrm{INS}} \\
\text { Fentanyl } \\
\text { FIBF } \\
\text { Heroin }\end{array}$ \\
\hline 34 & $\begin{array}{c}\text { Eutylone } \\
\text { Excipients: Caffeine }\end{array}$ & $\begin{array}{c}\text { Eutylone } \\
\text { Excipients: Caffeine }\end{array}$ & Eutylone \\
\hline 35 & $\begin{array}{c}\text { Fentanyl } \\
\text { Tramadol } \\
\text { Excipients: Caffeine, Levamisole, } \\
\text { Mannitol, Methoxpropamine, } \\
\text { Phenylpropanamide, Pindolol, Procaine }\end{array}$ & $\begin{array}{c}\text { Fentanyl } \\
\text { Tramadol } \\
\text { Excipients: Caffeine*, Levamisole, } \\
\text { Mannitol, Methoxpropamine, } \\
\text { Phenylpropanamide, Pindolol, Procaine }\end{array}$ & $\begin{array}{c}\text { Fentanyl } \\
\text { Tramadol }^{\mathrm{INS}}\end{array}$ \\
\hline 36 & AP-238 & $\begin{array}{c}\text { AP-238 } \\
\text { methyl Norfentanyl }{ }^{\dagger}\end{array}$ & AP-238 \\
\hline 37 & $\begin{array}{c}\text { Heroin } \\
\text { 6-Monoacetylmorphine }{ }^{\Delta}\end{array}$ & $\begin{array}{c}\text { Heroin } \\
\text { 6-Monoacetylmorphine } \\
\end{array}$ & Heroin \\
\hline 38 & $\begin{array}{c}\text { JWH-250 } \\
\alpha \text {-Methyl Fentanyl }\end{array}$ & $\begin{array}{c}\text { JWH-250 } \\
\alpha \text {-Methyl Fentanyl }\end{array}$ & $\begin{array}{c}\text { JWH-250 } \\
\alpha \text {-Methyl Fentanyl }\end{array}$ \\
\hline 39 & $\begin{array}{c}\text { Fentanyl } \\
\text { Excipients: Caffeine, Lidocaine*, } \\
\text { Quinine, Xylazine }\end{array}$ & $\begin{array}{c}\text { Fentanyl } \\
\text { 6-Monoacetylmorphine }{ }^{*, \Delta} \\
\text { Excipients: Caffeine, Lidocaine, } \\
\text { Mannitol*, Phenacetin*, Quinine, }^{*} \text { Xylazine }\end{array}$ & Fentanyl \\
\hline 40 & $\begin{array}{l}\text { 4-Chloroethcathinone } \\
\text { Cyclopropyl Fentanyl }\end{array}$ & $\begin{array}{l}\text { 4-Chloroethcathinone* } \\
\text { Cyclopropyl Fentanyl } \\
\text { Deschloroketamine }{ }^{*, \dagger}\end{array}$ & $\begin{array}{l}\text { 4-Chloroethcathinone } \\
\text { Cyclopropyl Fentanyl }\end{array}$ \\
\hline 41 & $\begin{array}{l}\text { No Controlled Substances } \\
\text { Excipients: Mannitol }\end{array}$ & $\begin{array}{l}\text { Cyclopropyl or Crotonyl Fentanyl } *, \dagger \\
\text { Excipients: Mannitol }\end{array}$ & No Controlled Substances \\
\hline 42 & $\begin{array}{c}\text { Acetyl fentanyl } \\
--- \\
\text { Fentanyl } \\
\text { FIBF } \\
\text { Heroin } \\
--- \\
\text { 6-Monoacetylmorphine }{ }^{\Delta} \\
\text { Excipients: Caffeine, Mannitol* }\end{array}$ & $\begin{array}{c}\text { Acetyl Fentanyl } \\
\text { Cocaine* } \\
\text { Fentanyl } \\
\text { FIBF } \\
\text { Heroin } \\
\text { Noscapine* } \\
\text { 6-Monoacetylmorphine*, } \\
\text { Excipients: Caffeine, Mannitol*, } \\
\text { Quinine }\end{array}$ & $\begin{array}{l}\text { Acetyl Fentanyl }{ }^{\mathrm{INS}} \\
\text { Cocaine }^{\mathrm{INS}} \\
\text { Fentanyl }^{\mathrm{INS}} \\
\text { FIBF }^{\mathrm{INS}} \\
\text { Heroin } \\
\text { Noscapine }\end{array}$ \\
\hline 43 & Methylone & Methylone & Methylone \\
\hline 44 & N-methyl Cyclopropyl norfentanyl & $\begin{array}{l}\text { N-methyl Cyclopropyl norfentanyl } \\
\text { 4-Acetoxy-DET } *, \uparrow\end{array}$ & N-methyl Cyclopropyl norfentanyl \\
\hline 45 & $\begin{array}{c}\text { No Controlled Substances } \\
\text { Excipients: Lidcocaine, Quinine }\end{array}$ & $\begin{array}{c}\text { No Controlled Substances } \\
\text { Excipients: Lidcocaine, Quinine }\end{array}$ & No Controlled Substances \\
\hline 46 & Methylethcathinone & Methylethcathinone & Methylethcathinone \\
\hline
\end{tabular}




\begin{tabular}{|c|c|c|c|}
\hline 47 & $\begin{array}{c}\text { JWH-018 } \\
\text { MDPV }\end{array}$ & $\begin{array}{c}\text { JWH-018 } \\
\text { MDPV }\end{array}$ & $\begin{array}{c}\text { JWH-018 } \\
\text { MDPV }\end{array}$ \\
\hline 48 & N-Ethyl pentylone & N-Ethyl pentylone & N-Ethyl pentylone \\
\hline 49 & MMB-FUBINACA & MMB-FUBINACA & MMB-FUBINACA \\
\hline 50 & $\alpha-\mathrm{PVP}$ & $\alpha-\mathrm{PVP}$ & $\alpha-P V P$ \\
\hline 51 & $\begin{array}{c}\text { Cocaine } \\
\text { Excipients: Levamisole }\end{array}$ & $\begin{array}{c}\text { Cocaine } \\
\text { Excipients: Levamisole }\end{array}$ & Cocaine \\
\hline 52 & $\begin{array}{c}\text { Cocaine } \\
\text { Excipients: Levamisole }\end{array}$ & $\begin{array}{c}\text { Cocaine } \\
\text { Excipients: Levamisole }\end{array}$ & Cocaine \\
\hline 53 & $\begin{array}{c}\text { Cocaine } \\
\text { Excipients: Levamisole }\end{array}$ & $\begin{array}{c}\text { Cocaine } \\
\text { Excipients: Levamisole }\end{array}$ & Cocaine \\
\hline 54 & Cocaine & Cocaine & Cocaine \\
\hline 55 & $\begin{array}{c}\text { Cocaine } \\
\text { Excipients: Phenacetin }\end{array}$ & $\begin{array}{c}\text { Cocaine } \\
\text { Excipients: Phenacetin }\end{array}$ & Cocaine \\
\hline 56 & $\begin{array}{c}\text { Cocaine } \\
\text { Excipients: Levamisole }\end{array}$ & $\begin{array}{c}\text { Cocaine } \\
\text { Excipients: Levamisole }\end{array}$ & Cocaine \\
\hline 57 & $\begin{array}{c}\text { Eutylone } \\
\text { Methamphetamine } \\
\text { Excipients: Caffeine }\end{array}$ & $\begin{array}{c}\text { Eutylone } \\
\text { Methamphetamine } \\
\text { Excipients: Caffeine }\end{array}$ & $\begin{array}{c}\text { Eutylone } \\
\text { Methamphetamine }\end{array}$ \\
\hline 58 & $\begin{array}{c}\text { Fentanyl } \\
\text { Excipients: Mannitol, Quinine, } \\
\text { Caffeine }\end{array}$ & $\begin{array}{c}\text { Fentanyl } \\
\text { Excipients: Mannitol, Quinine, } \\
\text { Caffeine }\end{array}$ & Fentanyl \\
\hline 59 & $\begin{array}{c}\text { Etizolam } \\
\text { Excipients: Caffeine, Quinine, } \\
\text { Diphenhydramine, Mannitol }\end{array}$ & $\begin{array}{c}\text { Etizolam } \\
\text { Excipients: Caffeine, Quinine, } \\
\text { Diphenhydramine, Mannitol* }\end{array}$ & Etizolam \\
\hline 60 & $\begin{array}{c}\text { MDA } \\
\text { Ketamine* } \\
\text { Excipients: Phenacetin }\end{array}$ & $\begin{array}{c}\text { MDA } \\
\text { Ketamine } \\
\text { Excipients: Phenacetin }\end{array}$ & $\begin{array}{c}\text { MDA } \\
\text { Ketamine }^{\text {INS }}\end{array}$ \\
\hline
\end{tabular}

* Denotes compounds that had relative intensities below $5 \%$ but above $2.5 \%$.

${ }^{\dagger}$ Denotes hits for controlled substances obtained in the DART-MS search that were not present in the sample.

${ }^{\Delta} 6$-Monoacetylmorphine was not noted as an additional identified substance because it is a breakdown of heroin.

INS Denotes compounds that were identified but were insufficient to report in the GC-MS result (defined as a peak in the chromatogram with less than 200,000 counts).

\section{Conclusions}

In this work, tetracaine was identified and evaluated as a candidate internal standard for the qualitative analysis of seized drugs by DART-MS. Tetracaine was found to be inexpensive, soluble in methanol at the necessary concentration, and did not interfere with detection of any commonly observed compounds of interest. Studies were conducted to determine an appropriate concentration for the internal standard to allow for identification of the same compounds as GC-MS while also minimizing the risk of false positive assignment of noise peaks. Competitive ionization due to the presence of tetracaine was observed for four of the six drugs investigated, but it did not cause complete suppression of the drug signal and the drug signals remained easily detectable. Analysis of case samples highlighted some of the benefits of incorporating an internal standard, including having a built-in mass calibration check, elimination of false positive identifications and having an indicator of analyte concentration. Using the internal standard allowed for automated mass drift compensation of data, removing a time-consuming step in highresolution DART-MS analysis. Inclusion of tetracaine as an internal standard does lead to the possibility of missing low-concentration components in drug mixtures. This is especially true for compounds with poorer ionization efficiencies such as heroin and noscapine. While this was an issue in only one of the case samples, it is something that chemists should be aware of. It can be mitigated by adding additional sample to the extract if desired. Current efforts are focused on further understanding the benefits and drawbacks of including an internal standard for 
qualitative analysis of seized drugs while also evaluating if tetracaine is a viable compound to also use as an internal standard for GC-MS analysis.

\section{Disclaimer}

Certain commercial products are identified in order to adequately specify the procedure; this does not imply endorsement or recommendation by NIST, nor does it imply that such products are necessarily the best available for the purpose.

Certain commercial products are identified in order to adequately specify the procedure; this does not imply endorsement or recommendation by Maryland State Police, nor does it imply that such products are necessarily the best available for the purpose.

A portion of this work was supported by Award No. 2018-DU-BX-0165, awarded by the National Institute of Justice, Office of Justice Programs, U.S. Department of Justice. The opinions, findings, and conclusions or recommendations expressed in this publication/program/exhibition are those of the author(s) and do not necessarily reflect those of the Department of Justice.

\section{Acknowledgments}

The authors would like to thank Robert (Chip) Cody for his assistance in developing the post-processing method on the JEOL system.

\section{References}

[1] R.B. Cody, J.A. Laeamee, D.H. Durst, Versatile New Ion Source for the Analysis of Materials in Open Air, Analytical Chemistry. 77 (2005) 2297-2302. https://doi.org/10.1021/ac050162j.

[2] E. Sisco, T.P. Forbes, Forensic applications of DART-MS: A review of recent literature, Forensic Chemistry. 22 (2021) 100294. https://doi.org/10.1016/j.forc.2020.100294.

[3] R.R. Steiner, R.L. Larson, Validation of the direct analysis in real time source for use in forensic drug screening, J. Forensic Sci. 54 (2009) 617-622. https://doi.org/10.1111/j.1556-4029.2009.01006.x.

[4] C.M. Longo, R.A. Musah, An Efficient Ambient Ionization Mass Spectrometric Approach to Detection and Quantification of the Mescaline Content of Commonly Abused Cacti from the Echinopsis Genus, Journal of Forensic Sciences. 65 (2020) 61-66. https://doi.org/10.1111/1556-4029.14134.

[5] K.L. Fowble, J.R.E. Shepard, R.A. Musah, Identification and classification of cathinone unknowns by statistical analysis processing of direct analysis in real time-high resolution mass spectrometry-derived "neutral loss" spectra, Talanta. 179 (2018) 546-553. https://doi.org/10.1016/j.talanta.2017.11.020.

[6] E. Sisco, E.L. Robinson, A. Burns, R. Mead, What's in the bag? Analysis of exterior drug packaging by TD-DART-MS to predict the contents, Forensic Science International. 304 (2019) 109939. https://doi.org/10.1016/j.forsciint.2019.109939.

[7] Validated Quantitative Methods DEA 101 - Quantitation of Cocaine by Gas Chromatography, Drug Enforcement Agency, 2019. https://www.dea.gov/sites/default/files/2019-

04/Summary\%20of\%20Validated\%20Quantitative\%20Methods.pdf.

[8] E. Sisco, J. Verkouteren, J. Staymates, J. Lawrence, Rapid detection of fentanyl, fentanyl analogues, and opioids for onsite or laboratory based drug seizure screening using thermal desorption DART-MS and ion mobility spectrometry, Forensic Chemistry. 4 (2017) 108-115. https://doi.org/10.1016/j.forc.2017.04.001.

[9] E.L. Robinson, E. Sisco, Detection of Brodifacoum and other Rodenticides in Drug Mixtures using Thermal Desorption Direct Analysis in Real Time Mass Spectrometry (TD-DART-MS), J. Forensic Sci. 64 (2019) 1026-1033. https://doi.org/10.1111/1556-4029.13978.

[10] E. Sisco, M.E. Staymates, T.P. Forbes, Optimization of confined direct analysis in real time mass spectrometry (DARTMS), Analyst. (2020). https://doi.org/10.1039/D0AN00031K.

[11] L. Song, S.C. Gibson, D. Bhandari, K.D. Cook, J.E. Bartmess, Ionization Mechanism of Positive-Ion Direct Analysis in Real Time: A Transient Microenvironment Concept, Anal. Chem. 81 (2009) 10080-10088. https://doi.org/10.1021/ac901122b.

[12] E. Sisco, T.P. Forbes, Rapid detection of sugar alcohol precursors and corresponding nitrate ester explosives using direct analysis in real time mass spectrometry, Analyst. 140 (2015) 2785-2796. https://doi.org/10.1039/c4an02347a.

[13] M. Doué, G. Dervilly-Pinel, K. Pouponneau, F. Monteau, B.L. Bizec, Direct analysis in real time - high resolution mass spectrometry (DART-HRMS): a high throughput strategy for identification and quantification of anabolic steroid esters, Drug Testing and Analysis. 7 (2015) 603-608. https://doi.org/10.1002/dta.1727. 
[14] K.L. Fowble, R.A. Musah, A validated method for the quantification of mitragynine in sixteen commercially available Kratom (Mitragyna speciosa) products, Forensic Science International. 299 (2019) 195-202. https://doi.org/10.1016/j.forsciint.2019.04.009.

[15] Mass Spectrometry Data Center, NIST, (n.d.). https://chemdata.nist.gov/ (accessed August 26, 2020).

[16] E. Sisco, A.S. Moorthy, L.M. Watt, Creation and Release of an Updated NIST DART-MS Forensics Database, J. Am. Soc. Mass Spectrom. 32 (2021) 685-689. https://doi.org/10.1021/jasms.0c00416.

[17] Monographs, (n.d.). https://www.swgdrug.org/monographs.htm (accessed April 21, 2021). 


\section{Supplemental Information}

Additional Information for the Measurement of Limits of Detection and Reporting Limits for GC-MS Systems.

In order to establish the limits of detection (LOD) and reporting limits for the GC-MS systems, a series of multicomponent solutions consisting of cocaine, fentanyl, and methamphetamine were created with concentrations ranging from $1 \mu \mathrm{g} / \mathrm{mL}$ to $300 \mu \mathrm{g} / \mathrm{mL}$. Solutions were prepared gravimetrically from $1 \mathrm{mg} / \mathrm{mL}$ stock solutions of the three compounds. Each concentration was then analyzed ten times on each GC-MS with the appropriate confirmation method. Peak heights for the three compounds were extracted from each data file. For determination of limit of detection, the peak heights were entered into the ASTM E2677 Limit of Detection Web Portal (https://www-s.nist.gov/loda/lod_description.htm), and the LOD was calculated using a $10 \%$ confidence limit. To determine the reporting limit, the peak height was plotted as a function of concentration and the concentration corresponding to peak height of 200,000 counts was extrapolated.
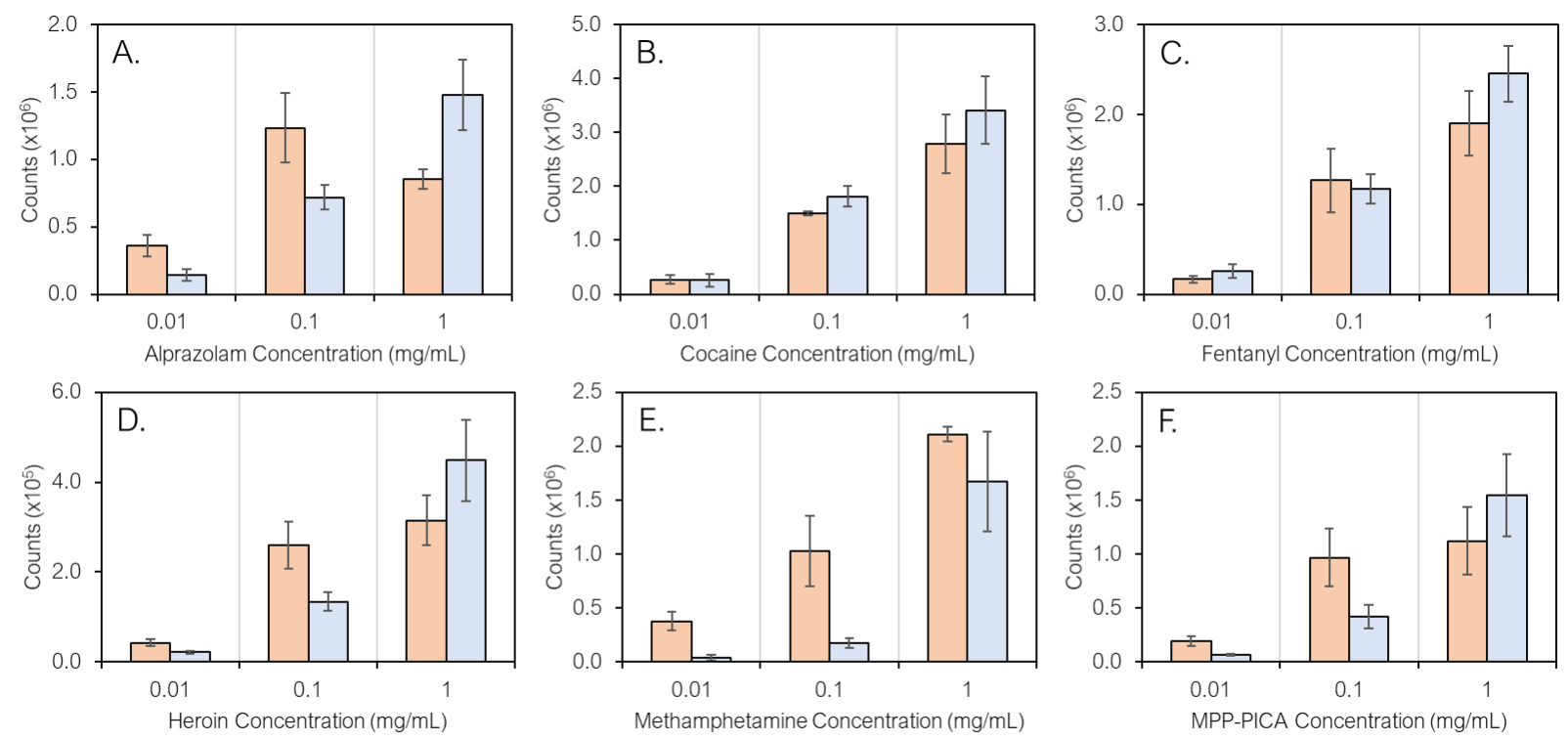

No Internal Standard $\quad \square$ With Internal Standard

Supplemental Figure 1. Plots of integrated peak area of protonated molecules for alprazolam (A.), cocaine (B.), fentanyl (C.), heroin (D.), methamphetamine (E.) and MPP-PICA (F.) when analyzed with (blue) and without (orange) internal standard. Uncertainties represent the standard deviation of five replicates. 